\title{
The indications and reliability of vein graft use in free flap transfer
}

\author{
Dale A Classen MD FRCSC
}

DA Classen. The indications and reliability of vein graft use in free flap transfer. Can J Plast Surg 2004;12(1):27-29.

BACKGROUND: Adequate recipient vessels are critical for free flap success. There are, however, situations in which the local recipient vessels are inadequate. In these situations, vein grafts are required to allow pedicle extension to recipient vessels.

OBJECTIVES: To determine the indications, technique, reliability and outcome of vein graft use in free flap transfer.

METHODS: A retrospective review of 198 consecutive free flaps by a single surgeon.

RESULTS: Vein grafts were required in $9.6 \%$ of free flaps. The most common indication was vein graft use in a planned preoperative fashion. The vein graft was most commony placed as an arteriovenous fistula loop. There was no statistically significant difference in survival between flaps with or without vein grafts.

CONCLUSION: Vein graft use in free flap transfer is reliable, effective and often necessary for free flap survival.

Key Words: Free flap; Vein graft

\section{Les indications et la fiabilité de l'utilisation de la greffe veineuse en cas de transfert de lam- beau libre}

HISTORIQUE : Il est essentiel de disposer de vaisseaux récepteurs convenables pour assurer la survie d'un lambeau libre. Toutefois, dans certains cas, les vaisseaux récepteurs ne conviennent pas. Il faut alors utiliser une greffe veineuse pour permettre l'extension pédiculaire des vaisseaux récepteurs.

OBJECTIFS : Déterminer les indications, la technique, la fiabilité et les issues de l'utilisation d'une greffe veineuse en cas de transfert de lambeau libre.

MÉTHODOLOGIE : Analyse rétrospective de 198 lambeaux libres transférés par un même chirurgien.

RÉSULTATS : Des greffes veineuses ont été nécessaires dans 9,6\% des lambeaux libres. L'indication la plus courante était une greffe veineuse planifiée en période préopératoire. La plupart du temps, la greffe veineuse était placée dans l'anse d'une fistule artérioveineuse. On ne remarquait aucune différence significative de la survie des lambeaux avec ou sans greffe veineuse.

CONCLUSION : L'utilisation d'une greffe veineuse en cas de transfert de lambeau libre est fiable, efficace et souvent nécessaire pour assurer la survie du lambeau libre.
$\mathrm{T}_{\mathrm{f}}^{\mathrm{h}}$ he proper selection of recipient vessels is critical for free flap success. Undamaged recipient vessels that are available adjacent to a wound are best used to minimize the length of flap pedicle required. There are, however, situations in which the local recipient vessels are inadequate due to the anatomical location of the wound, or due to the fact that the local vessels may be diseased or damaged. In these situations, pedicle extension of the free flap will be required with vein grafts to reach suitable recipient vessels.

Reports in the literature are conflicting with respect to the reliability of vein graft use in free flap surgery. There are some reports of an increased incidence of free flap failure with vein graft use (1-5). There are other reports that do not show an increased risk of flap loss with vein graft use (6-8).

This study was undertaken to determine the indications, technique, reliability and outcome of vein graft use in free flap surgery in the author's experience over the last nine years.

\section{PATIENTS AND METHODS}

One hundred ninety-eight consecutive free flaps were performed on 184 patients from January 1994 to December 2002. Data were collected on these patients in a microsurgical data base and this information was reviewed for patient demographics and specifically vein graft use and outcomes.

The most common indication for free flap transfer was trauma (Figure 1). The recipient site was most commonly the lower extremity (Figure 2 ). The most common free flap transferred was a muscle flap (Figure 3).

Vein grafts were required in a total of 19 free flaps (9.6\%). Vein grafts were used in three different clinical scenarios. Most commonly, vein grafts were used in a planned fashion in which preoperative planning identified a situation in which local recipient vessels would be unavailable due to disease, trauma, or anatomical location of the wound ( 15 cases). A second clinical scenario for vein graft use was for flap salvage in cases of postoperative venous 


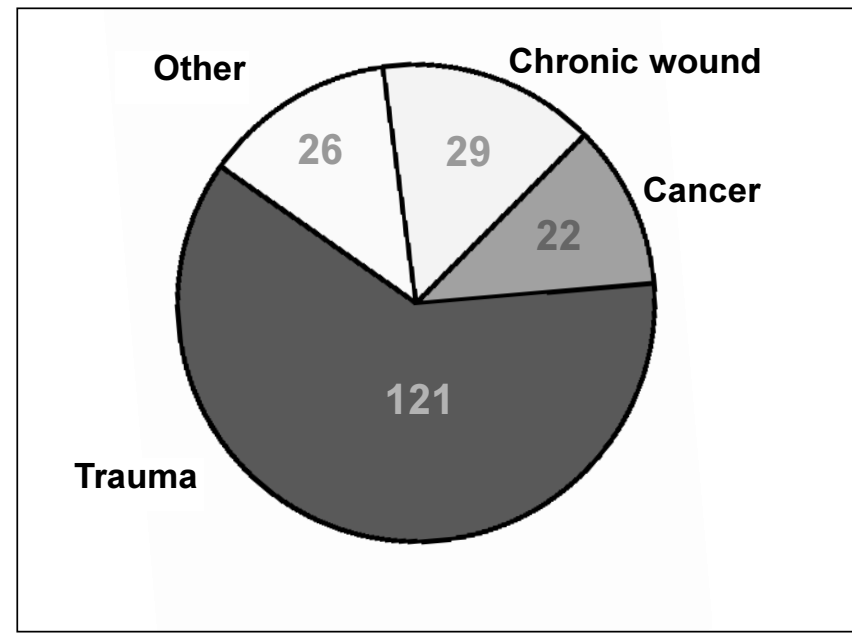

Figure 1) Recipient site condition

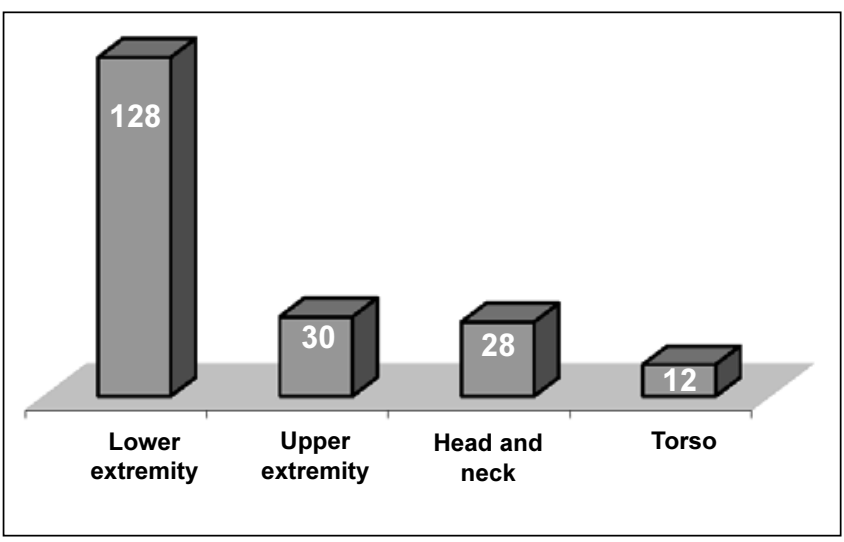

Figure 2) Recipient site

thrombosis (two cases). The third clinical scenario was use of vein grafts in an unplanned intraoperative fashion (two cases).

In the most common scenario for vein graft use - planned preoperative fashion - the anatomical recipient site and vein graft use is seen in Figure 4. The greater saphenous vein was used in 15 of 15 cases. In 13 of 15 cases, both the artery and vein were grafted, using the technique of creation of an arteriovenous fistula loop. The arterial anastomosis was performed end-to-side in nine of 13 cases, and end-to-end in four of 13 cases. The venous anastomosis was end-to-side in three cases, end-to-end in four cases and in six cases the saphenous vein was left in situ and there was no proximal venous vein graft anastomosis required. In two of 15 cases, only the artery required grafting. The average length of vein graft required was $19 \mathrm{~cm}$ (range, $7 \mathrm{~cm}$ to $35 \mathrm{~cm}$ ).

\section{RESULTS}

The overall success in this series was $96 \%$. The re-exploration rate was $3 \%$, with a salvage rate of $50 \%$ (three of six cases). Vein grafts were required in 19 cases (9.6\%). Free flaps with vein grafts were successful in 14 of 15 cases (93\%) when vein grafts were used in a planned preoperative fashion. Free flaps with vein grafts were successful in two of two (100\%) when used for flap re-exploration for salvage of venous thrombosis. Free flaps were successful in one of two cases (50\%) when vein

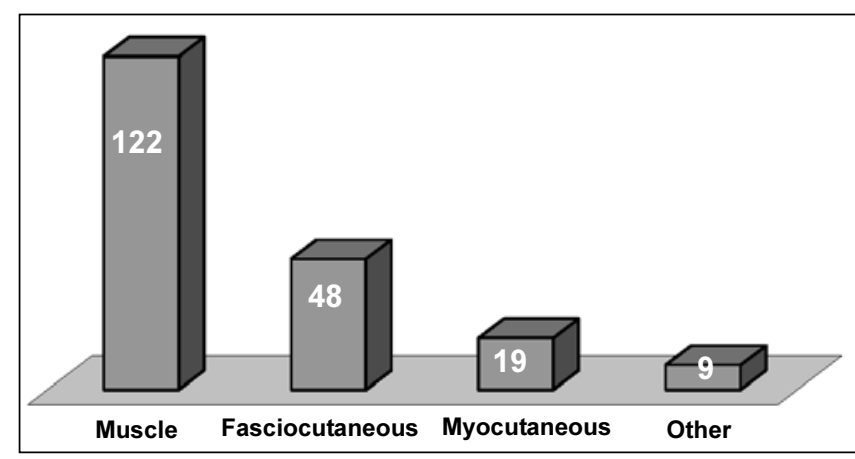

Figure 3) Free flap donor site

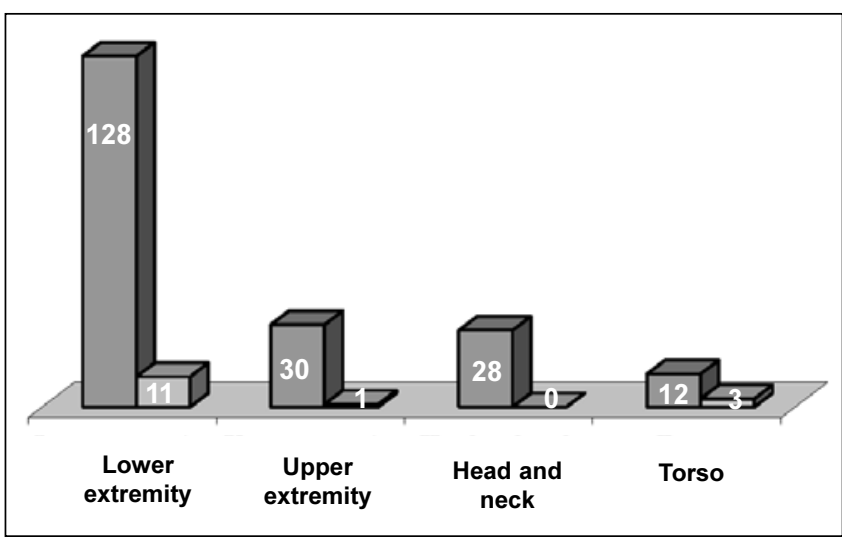

Figure 4) Vein graft requirement and recipient site

grafts were used in an unplanned intraoperative situation. Table 1 compares survival rate of flaps with and without vein graft use. There was no statistically significant difference in free flap survival rates between flaps with and without vein graft use.

\section{DISCUSSION}

Vein grafts are necessary during free flap transfer when pedicle extension of the free flap is required to reach recipient vessels. In this series of patients, vein grafts were required in approximately $10 \%$ of the free flaps. Reports in the literature of relatively large series of free flaps indicate the requirement for vein grafts in the range of $5 \%$ to $25 \%(5-9)$.

Vein grafts were used most commonly in the situation of preoperative planning (15 cases), identifying a situation of inadequate vessels due to trauma, disease or anatomical location of the wound. In this situation, vein graft use with free flaps was successful in 14 of 15 cases (93\%) in comparison with $97 \%$ in those flaps not requiring vein grafts. This is consistent with the experiences of Dr Acland (10), who believed that planned vein grafts generally do well. The technique used was creation of a temporary arteriovenous fistula loop in 13 of 15 cases. This is a well established technique $(9,11-13)$. The advantage of placing the vein grafts in an arteriovenous fistula loop is that it allows for physiological distention of the graft before anastomosis to the flap pedicle. This ensures patency of the anastomosis, ensures no twists or kinks, and allows a check of any leaks before flap harvest, thus minimizing flap ischemia time. An alternative technique for placement of the vein graft 
TABLE 1

Survival rate of flaps with and without vein graft use

\begin{tabular}{lcc}
\hline & $\begin{array}{c}\text { Free flaps without } \\
\text { vein grafts }\end{array}$ & $\begin{array}{c}\text { Free flaps with } \\
\text { vein grafts }\end{array}$ \\
\hline Number & 179 & 19 \\
Survival rate $(\%)$ & 97 & 90 \\
\hline
\end{tabular}

$P=0.172$

is to place the graft on the flap pedicle first (10). This technique was not used in this series.

There are reports of creation of a temporary arteriovenous fistula loop days to weeks before transfer of the free flap, thus making the flap transfer a two stage procedure $(13,15)$. This technique seems to have a higher failure rate than single stage creation and flap transfer. In this series, an arteriovenous loop was created and free flaps were transferred in a single stage.

In the the lower extremity, if the ipsilateral greater saphenous vein could be used for creation of the arteriovenous fistula loop, the proximal end was left in situ for venous drainage. This eliminated the need for anastomosis of the venous end of the graft. This was done in six of 13 arteriovenous loops. If the contralateral saphenous vein was used, then naturally both arterial and venous anastomoses were required for creation of the arteriovenous loop (seven of 13 cases). The average length of the vein grafts was $19 \mathrm{~cm}$, with six cases requiring a graft vein of greater than $20 \mathrm{~cm}$. Reports in the literature do not suggest that vein graft length impacts on patency rates $(10,14)$.

In this series of 198 free flaps, flap re-exploration was required in six cases (3\%) with salvage of three of six cases $(50 \%)$. In two cases of salvage re-exploration, excision of the thrombosed venous segment and vein graft interposition was successfully performed to allow pedicle extension to the recipient vein in a more proximal position. When re-exploring flaps for pedicle thrombosis, liberal use of vein grafts to replace damaged segments of vein would appear justified.

In two cases in this series, vein grafts were used in an unplanned fashion due to unexpected intraoperative occurrences. In one case, an intraoperative venous thrombosis occurred and was detected before flap inset. This was successfully treated with excision of the damaged recipient vein and interposition of a $7 \mathrm{~cm}$ segment of vein graft for successful flap survival. The initial thrombotic event could have likely been prevented by first recognizing the damaged recipient vein and placing a vein graft initially in a planned fashion. In the second case, an unexpectedly short pedicle could not reach recipient vessels. This was not recognized until after flap harvest. Flap failure occurred due to prolonged flap ischemia despite attempted salvage with vein graft extension. This flap loss likely could have been avoided by preoperative planning and early placement of vein grafts before flap harvest.

A general principle in free flap surgery is to use recipient vessels that are free of disease. In most cases, the free flap pedicle can reach recipient vessels directly. Some techniques may allow free flap anastomosis in the lower extremity near the zone of injury avoiding the use of vein grafts $(16,17)$. If possible, one should avoid using vein grafts as they do increase the complexity of the surgery. There are, however, situations that necessitate vein graft extension of the pedicle of the free flap to reach appropriate recipient vessels. When vein grafts are used in a planned fashion, they are reliable and effective. This series of patients is consistent with other reports in the literature $(6-8)$ and demonstrates that there is no statistically significant difference in free flap survival rates between flaps with or without vein grafts. The most common indication in this series was the use of vein grafts in a preoperative planned fashion.

\section{REFERENCES}

1. Khouri RK, Cooley BC, Kunselman AR, et al. A prospective study of microvascular free flap surgery and outcome. Plast Reconstr Surg 1998;102:711-21.

2. Suominen S, Asko-Seljavaara S. Free flap failures. Microsurgery 1995;16:396-9.

3. Miller MJ, Schusterman MA, Reece GP, et al. Interposition vein grafting in head and neck reconstructive microsurgery. J Recontr Microsurg 1993;9:245-51.

4. Khouri RK, Shaw WW. Reconstruction of the lower extremity with microvascular free flaps. A 10 year experience with 304 consecutive cases. J Trauma 1989;29:1086-94.

5. Schusterman MA, Miller MJ, Reece GP, et al. A single center's experience with 308 free flaps for repair of head and neck cancer defects. Plast Reconstr Surg 1994;93:472-8.

6. Bayramicli M, Tetik C, Sonmez A, et al. Reliability of primary vein grafts in lower extremity free tissue transfers. Ann Plast Surg 2002;48:21-9.

7. Germann G, Steinau H. The clinical reliability of vein grafts in free-flap transfer. J Reconstr Microsurg 1996;12:11-7.

8. Vlastou C, Earle AS, Jordan R. Vein grafts in reconstructive microsurgery of the lower extremity. Microsurgery 1992;13:234-5.

9. Freedman AM, Meland NB. Arteriovenous shunts in free vascularized tissue transfer for extremity reconstruction. Ann Plast Surg 1989;23:123-8.

10. Acland RD. Refinements in lower extremity free flap surgery. Clin Plas Surg 1990;17:733-44.

11. Hallock GG. The interposition arteriovenous loop revisited. J Reconstr Microsurg 1988;4:155-9.

12. Angel MF, Chang B, Clark N, et al. Further clinical use of the interposition arteriovenous loop graft in free tissue transfers. Microsurgery 1993;14:479-81.

13. Atiyeh BS, Khalil IM, Hussein MK, et al. Temporary arteriovenous fistula and microsurgical free tissue transfer for reconstruction of complex defects. Plast Reconstr Surg 2001;108:485-8.

14. Karanas YL, Yim KK, Johannet P, et al. Use of $20 \mathrm{~cm}$ or longer interposition vein grafts in free flap reconstruction of the trunk. Plast Reconstr Surg 1998;101:1262-7.

15. Ritter EF, Anthony JP, Levin LS, et al. Microsurgical composite tissue transplantation at difficult recipient sites facilitated by preliminary installation of vein grafts as arteriovenous loops. J Reconstr Microsurg 1996;12:231-9.

16. Isenberg JS, Sherman R. Zone of injury: A valid concept in microvascular reconstruction of the traumatized lower limb? Ann Plast Surg 1996;36:270-2.

17. Kolker AR, Kasabian AK, Karp NS, et al. Fate of free flap microanastomosis distal to the zone of injury in lower extremity trauma. Plast Reconst Surg 1997;99:1068-73. 